\title{
DEVELOPING LOCAL CONTENT-BASED INSTRUCTIONAL GRADED READING MATERIALS FOR READING LEVEL THREE STUDENTS
}

\author{
Shella Monica ${ }^{1}$ \\ IAI Al-AzhaarLubuklinggau \\ MachdalenaVianty ${ }^{2}$ \\ Universitas Sriwijaya \\ ausyshella@yahoo.com ${ }^{1}$
}

Submit, 30-07-2019 Accepted, 27-08-2019 Publish, 29-08-2019

\begin{abstract}
This research aimed at analyzing the quality of the newly developed local-contentbased instructional graded reading materials for junior high school students in Lubuklinggau. The development of the instructional materials was then analyzed and evaluated in terms of their validity, practicality, and effectiveness using formative evaluation proposed, which consists of self-evaluation, experts review, one-to-one, small group, and field test. The result of expert review showed that the prototype of the product was categorized as having high validity as indicated by the average score of questionnaires on content and construct which was 3.23 (scale 1-4). Moreover, developed instructional reading materials were also considered as highly practical as indicated by the average score of one-to-one evaluation (3.39) and small group evaluation (3.18). Meanwhile, the result of field test evaluation showed that the developed reading comprehension test was highly effective to be used as reading assessment. Meanwhile, the result of field test evaluation shows that developed test could be categorized as effective because there were 20 students $(74.07 \%)$ out of 27 students in reading comprehension test reached average category which was between 56 and 70 . Hence, it was concluded that the developed products, either the test or the teaching materials can become alternative for teaching reading to students whose level of reading is level 3.
\end{abstract}

Keywords: reading assessment; graded reading material; local contentagriculturalproduct

\section{INTRODUCTION}

As the largest archipelago country in the world, Indonesia absolutely has a rich local content (Riyadi, 2004:1). National Resource Governance Institute (2015:1) states, "Local content is the value that an extraction project brings to the local, regional or national economy beyond the resource revenues." Local content products bring such a benefit to the Indonesian local communities especially in improving local economy. A great example comes from its agriculture field; 
World Bank (2003) explains that historically, Indonesian agriculture has performed well, and its agricultural products significantly contributed to Indonesia's growth, bringing with it significant increases in employment and a remarkable reduction of poverty.

However, as a matter of fact, Ubbe (2011:23) points out that Indonesia doesn't paid attention on protecting and even promoting its local content products, as the result, Indonesian local content can be claimed by other countries. Baswedan, Srihadi, Yusuf, Koban, and Yuda (2010:89) reported that there are at least 21 Indonesian local contents have been claimed by the neighbor country, Malaysia. Unfortunately, Malaysia not only claimed some of Indonesian cultural products including traditional dances, songs or music instruments, but also one of Indonesian traditional foods; it was Rendang from West Sumatera. This problem clearly reflects how weak Indonesia is in securing the wealth of its local content.

Therefore, lack of appreciation of local content products on the part of the public nowadays becomes the biggest concern for related government in Indonesia. Education sector regarded as an appropriate forum for fulfilling the aim of local content promotion. By establishing the Ministry of National Education Decrees Number 22 and 23/2006, Indonesian government, gives a big chance for local content to being integrated on various school subjects either in curriculum of primary (basic) or in secondary education.

In addition, English also plays an important role in responding this challenge. It is widely recognized that English is important for Indonesia and the reason most frequently put forward this is that English is a global or international language, thus the local content products regarded, would be effectively exposed to the world if it is delivered in English (Lauder, 2008:90). Responding the previous argument, Prastiwi (2013:23), emphasizes that EFL teachers should make use of EFL teaching learning process as a way to serve a dual purpose; supporting mastery of the target language (L2) and fulfilling the obligation to introduce the local culture/content $(\mathrm{C} 1)$ particularly within the young generations. Hence, the term materials in ELT expected are not limited only to the cultures of native English-speaking countries but should allow for local cultural content (Richard, 2005:45)

Furthermore, Local content-based materials revealed bring such a benefit contribution to ELT especially in improving student's reading comprehension. Utami, Nitiasih and Artini (2014:98) found that involving culture or local content in reading materials can effectively help students to gain more understanding toward the content, since it closes to their daily life. In line with the previous arguments, Malone (2013:20) states thatthe alternative way that can be used by EFL teacher to help the students become life-long readers is by providing the students with information or reading materials which are relevant to students' life, 
heritage and culture, such as the story from the local content dealing with local people, object and events.

In contrast with what was expected, although the use of local contentbased material is highly recommended and stated in the curriculum, the number of local content-based material is still limited in Indonesia. According to Pitaloka (2014:12), there were some problems in the English text-books used in Indonesia which are concerned with the limitation of local content-based materials and the inappropriate readability of the texts used. In line with Pitaloka's findings (2014:45), through instructional analysis, the writer found that, the English teachers of SMP Negeri 11 Lubuklinggau only used one English course book that lack of local content-based material, moreover, that textbook was also offering the reading comprehension test which providing the descriptive texts with readability levels was irrelevant to the students' reading level as indicated at level 3.

The results of analyses above clearly reflect the quality of the instructional reading materials in SMP N 11 Lubuklinggau which was regarded still ineffective and encountering some problems dealing with students reading literacy. Waugh and Gronlund (2013:34) point that reading assessment (including texts and comprehension questions) is much needed in ELT, while it is used as a tool in determining to which students are achieving the intended learning outcomes of reading instruction. Meanwhile, as nonfiction genre, descriptive text regarded important to be introduced to the young learners as soon as possible, because it is clearly recognized that when students learn nonfiction genres they actively engage with the world outside themselves (Borner, 1995:90). As the native of Lubuklinggau, the writer, therefore, was encouraged to develop descriptive texts completed by comprehension questions with the theme of which were focused on Lubuklinggau local content.

According to Central Bureau of Statistics of Lubuklinggau (2013), Lubuklinggau has some districts which have great potential in the field of agriculture, especially in the terms of plantation, horticultural and other agriculture subsectors, the existence of this sector is not only quite important in meeting the needs of food for Lubuklinggau community, but also give an important contribution in improving the economy sector (Lubuklinggau, 2013). As an attempt of preserving local identity, the Mayor of Lubuklinggau's regulation number 31 Year 2014 emphasizes that the local content product of Lubuklinggau must be preserved, promoted and protected intensively in supporting the development of Lubuklinggau city.

Responding the idea of local content promotion and the factual condition of reading material in Indonesia, therefore, the aim of this study was to develop local content-based instructional graded reading materials with the theme of which was focused on agricultural product of Lubuklinggau which were valid, 
practical, and effective for reading level three students. Furthermore, the developed product expected could be effectively exposed to the young generation and would not be vanished from its existence as a part of precious local content products of Indonesia in this globalization era.

\section{LITERATURE REVIEW}

\section{Material Development}

Materials can be developed by government, private publishers, researchers, or teachers. Tomlinson (2012:93) asserts that materials development can be defined as all the processes carried out by practitioners who intend to produce and/or employ materials for language learning in which the processes include materials evaluation, their adaptation, design, production, exploitation and research. Ideally, all of these processes should be taken into consideration and should be collaborated for the purpose of developing language-learning materials.

Richards (2005:76) states that effective instructional materials in language teaching are shaped by considering three factors: teacher, learner, and contextual variables. Considering this argument, in planning a new textbook or course book series the publisher is normally providing the writer with a profile of the target teachers, learners, and teaching context in order to enable the writer to tailor the materials to the target audience (Tomlinson, 2011:92). Responding the previous explanation, the teachers are expected can develop learning material which is according to the students' real live.

\section{Reading Comprehension}

One of the priority purpose of teaching English as a foreign language to Indonesian peopleis that they can read in order to grasp the idea and to understand the book that is written in English.According to Addison (1996:3), "Reading is an active process in which readers shift sources of information (what they know and what the text says), elaborate meaning and strategies, check their interpretation (revising when appropriate) and use the social context to focus their response". Regarding that explanation, Kellerman (1996:23) states if the students cannot read they will have low achievement, so they are on the road to academic failure. Teaching students to read must be highest priority. The ability to read is crucial for all students in reaching both the academic and society success. Cooper, Warncke, and Shipman (1998:24) divide reading achievement into five categories (1) meaning vocabulary in which the reader is concerned with learning the meaning of words he or she reads; (2) literal comprehension is concern with the information and idea that are explicitly stated in the selection; (3) inferential comprehension is concerned with drawing conclusion, generalizing or interpreting what is read; (4) applied comprehension is implicit schema that requires 
integration of new information into the readers' previous knowledge, from which new relationships emerge; and (5) critical reading requires reading with an inquiring mind and with active, creative looking for false statements.

Moreover, Cooper, Warncke, and Shipman (1988:90) state that there are some reading skills which should be mastered by the students including the ability to answer question about main idea (MI), detail (D), Sequence (Sq), Inference (If), Reference $(\mathrm{R})$, cause effect $(\mathrm{C} / \mathrm{E})$, and vocabulary $(\mathrm{V})$. Regarding the previous explanation, to measure students' reading comprehensions, all of reading skills above were all included or tested both in reading exercises and reading comprehension test in this study.

\section{Local Content}

Definition of local content is difficult to find. Ballantyne (2002:32) argues that there are some definitions of local content; some people define it as content for people in a certain locality, or content for people speaking a language or for people from a cultural tradition, others suggest it is a content that is relevant to, or consumed by a given society or community in which they live and work, finally in his study, he concludes that local content is the expression of the locally owned and adapted knowledge of community, and these communities may be defined by their location, culture, language, religion, ethnicity or area of interest.

Meanwhile, National Resource Governance Institute (2015:60) defines local content as the value that an extraction project brings to the local, regional or national economy beyond the resource revenues consisting oil and gas, chemicals, information, metals, food, culture, transportation equipment, electrical, professional services, agriculture, and textiles. Country can encourage its local content through requirements and targets written in national laws and individual contracts. Local content gives such a benefit to the local communities especially in improving local economy. For example, in agriculture field, World Bank (2003) explains that historically, Indonesian agriculture has performed well; it did by focusing on the staple food crops such as rice, corn, sugar and soybeans, then these agriculture products contributed significantly to Indonesia's growth, bringing with it significant increases in employment and a remarkable reduction of poverty. Meanwhile, since developed products in this study are given to the eighth grade students in Lubuklinggau therefore, developed graded reading material in this study containedLubuklinggau local content, the theme of which was focused on its agricultural products.

\section{Local Content-Based in EFL Context}

Teaching a language cannot be separated from teaching its culture. According to Avruch (1998:6), "culture is that complex whole which includes 
knowledge, belief, art, morals, law, custom, and any other capabilities and habits" Meanwhile, Brown (2007:45) defines culture as something which is definitely an integral part of the interaction between language and thought. Thus, in terms of ELT, teachers have to teach English as the target language (L2) along with its culture (C2). There is another way to teach English (L2) which is by using local culture $(\mathrm{C} 1)$.

Moreover, Richards (2005:78) argues that the use of local cultural/content material in the teaching of English as a foreign language serves a dual purpose: supporting mastery of the target language (L2) while also enabling teachers to fulfill their obligation to teach about local culture (C1).

Actually, Indonesian government already supports the implementation of local content material in education; it is by establishing the Ministry of National Education Decrees Number 22 and 23/2006. In this act, the government expect the local content can be incorporated into various school subjects either in curriculum of primary (basic) or in secondary education, unfortunately in this respect, the term of local content defines as curricular activities in order to develop competency adjusted with unique local characteristics and potential, including local advantages where the content cannot be clustered into the existing subjects (Dharma, 2008:92). Therefore, considering the explanations above, it could be concluded that local content-based materials has important role in education. It is beneficial, not only for improving students' reading comprehension, but also for enriching their local content knowledge.

\section{Graded Reading Material}

Macmillan Education (2014:23) states that graded reading materials or graded readers are short books and audio books, encompassing both fiction and non-fiction genres which is written in various levels of reading, so the students will find the quick and easy to read. Furthermore, levels in graded reading material are carefully graded from starter to upper intermediate to help the students choose the right material for their ability. In other words, it offers a wide and attractive range of short, learner-friendly books which can be read quickly, easily and enjoyably.

Moreover, Nation and Ming-tzu, (1999:356) point out that graded readers has long been recognized as a book or reading material which are specially written or adapted for second language learners. It involves severely restricting the vocabulary and controlling the grammatical structures that occur, and matching the length of text to the vocabulary and grammar controls. Hence, reading graded readers can have several learning goals in ELT. These include gaining skill and fluency in reading, establishing previously learned vocabulary and grammar, learning new vocabulary and grammar, and gaining pleasure from 
reading.Typically, a graded reading scheme consists of a series of vocabulary and grammar levels with several readers available at each level of the scheme. A low proficiency learner would begin read this reading book at the lowest level of the scheme, and when reading at that level was comfortable, could move to the book at the next level.

By considering the reading level of the Eighth grade students, which were in level 3 , therefore the writer wrote 5 passages which were covering 5 reading levels $(1,2,3,4$, and 5). Each reading passage was calculated in term of its readability level using online tool named Automated Readability Index (i.e.: https://readability-score.com/). Furthermore, those passages were graded from the lowest level to the highest one.

\section{RESEARCH METHOD}

The product in this study which consists of reading material and reading comprehension test was developed by using the procedure of developmental research proposed by Akker (1999:67) consisted of analysis, design, evaluation, and revision. In analysis stage, the three main activities were conducted consisting of instructional analysis, students' needs analysis and students' reading level analysis. First, in instructional analysis, the writer analyzed the curriculum and the textbook used by the eighth grade students in SMP N 11 Lubuklinggau. Next, in needs analysis, students' problems and needs toward their reading teaching and learning were determined through needs analyses sheet. Finally, in reading level analysis, students' reading level was also determined by A Group Informal Reading Inventory: An Instrument for the Assessment of ESL Students 'Reading Performance developed by Stark (1981:45).

In design stage, the results of analysis were used as the guideline in developing local content-based instructional graded reading materials. Then after the product was developed, in evaluation stage, developed product was analyzed and evaluated in terms of its validity, practicality and effectiveness (reading comprehension test) using the formative evaluation proposed by Tessmer (1993:12) which consists of self-evaluation, expert review, one-to-one evaluation, small group evaluation, and field test.

In expert review phase, two experts were involved to evaluate the validity of developed instructional reading materials in terms of its content (English) and construct (instructional design). Meanwhile, 35 eighth grade students in SMP N 11 Lubuklinggau was then involved in three different evaluation phases; 3 students (1 student for each category of reading level, i.e.: low, medium, and high reading level) participating in one-to-one evaluation, 9 students (3 students for each category of reading level, i.e.: low, medium, and high reading level) 
participating in small group evaluation and other 27 students participating in field test.

Three different questionnaires in form of likert scale (adapted from Tessmer, 1993:45) consisted of questionnaire for expert of content, questionnaire for expert of construct, and questionnaire for students' responses were then used as the instrument of the study. The validity of the product was indicated by calculating the average score of the two questionnaires (content and construct) given by two experts in experts review phase. Meanwhile, the practicality of the product was determined from the result of questionnaire given by the students in one-to-one and small group evaluation. All questionnaires in this study were interpreted into very high (3.26-4.00), high (2.52-3.25), low (1.76-2.50), and very low (1.00-1.75) with the interval of the scale was 1-4 (Kubisxyn\&Borich, 1993).

Meanwhile, in field test phase, 27 students were involved. In the field test phase, the effectiveness of developed reading comprehension test was measured. It was done by administering developed reading comprehension test to the students. The test can be considered effective if $70 \%$ or more students reach average which was between 56 and 70 in the reading comprehension test. Furthermore, the criterion related validity of the developed reading comprehension test was measured by calculating the coefficient correlation of the students' scores in comprehension test to which they obtained in standardized test (IRI). The strength of the relationship between those two sets of scores was given by the Pearson correlation (symbolized by R). The sign of the correlation coefficient was determined whether the correlation was positive or negative. Meanwhile, the strength of the correlation was determined by the magnitude of the $\mathrm{R}$ value which was interpreted into low (0.00-0.30), moderate (0.31-0.60), strong (0.61-0.90, and very strong (0.91-1.00) (Noble, 2014:67).

In addition to the criterion related validity, the writer also measured the reliability (determined through Cronbach Alpha), items validity (determined through Pearson product moment), index of difficulty and discrimination index of the developed reading test (determined through Heaton's formula, 1989:45) statically by using SPSS 22 . The test was may be considered reliable if the value of Cronbach's Alpha obtained is at 0.70 (Hughes, 1989:34). Moreover, the validity of each item of test was interpreted by following the criterion validity proposed by Saad, Carter, Rothenberg, and Enid, (1999:78) which was categorized into very beneficial (above .35), likely to be useful $(.21-.35$ ), depends on circumstances (.11 - .20), unlikely to be useful (below .11).

Additionally, index of difficulty was interpreted into very difficult (FV $\leq 0.00)$, difficult $(0.00<F V \leq 0.30)$, medium $(0.31<F V \leq 0.70)$, easy $(0.71<F V \leq$ $1.00)$ and very easy $(\mathrm{FV}<F V \leq 1.00)$, while, discrimination index of items was categorized into failed $(D \leq 0.00)$, bad $(0.01<D \leq 0.20)$, moderate $(0.22<D \leq$ 
$0.40)$, good $(0.41<D \leq 0.70)$, excellent $(0.71<D \leq 1.00)$ with the interval of the score was 0.00 - 1.00 (Subana and Sudrajat, 2005:78).

\section{FINDING}

\section{Analysis phase}

\section{Instructional analysis}

In this analysis, the write finally found the results that describe below:

1. The number of the local content-based descriptive texts available in the textbook was still insufficient.

2. The readability levels of the texts included in the textbook were not relevant to the students' reading level as indicated at Level 3.

3. The use of local content-based instructional reading materials for the Eighth grade students in SMP N 11 Lubuklingau is in line with the curriculum.

\section{Student Needs analysis}

The results of the student need analysis are described as follows:

1. 59.2\% of 27 students stated that they had poor skill in comprehending English texts. It was caused its readability of reading materials in the textbook which was not relevant to their reading levels (92\%). Moreover, they also thought that the topics of texts did not match their interest (37\%).

2. The students' perception towards the reading activity varied from enjoyable to very joyless, but no student felt at very enjoyable. As the students stated, in teaching reading their English teacher only use one English textbook (100\%).

3. The students mostly found it difficult to comprehend the descriptive text. as the students stated, the level of the texts and the topics of the texts were not match with their reading skill and social live. They suggested that descriptive text had to have picture to make them easier in comprehending it.

4. All students very like the texts containing their local content. They, however, had never been provided English texts containing the topic which is relevant to their local content (100\%).

5. Students mostly are familiar with the name of Lubuklinggau agricultural products, but they do not all understand in details about the differences and the characteristics of them. Furthermore they expected that descriptive texts containing Lubuklinggau local were provided.

Moreover, to make sure the student's statements in need analysis phase, the writer also did unstructured interview to their teachers, some questions related to teaching and learning process in reading activity were asked to the teachers. As the result, the teachers also confessed that local content-based reading materials were needed to be provided in order to improve students' reading comprehension and enrich their local content knowledge. From the results of the needs analysis above, the write drew the following conclusions. 
1. Local-content-based descriptive texts with the theme which focused on agricultural products (i.e.: the descriptions about Batok sugar, coconut sugar, butter avocado, and three kinds of yam) were needed to be developed. When reading materials are about something that is familiar to them, the readers can use their own knowledge and experience to help them understand the written text (Malone, 2013).

2. Local content-based graded reading materials had to be provided with the appropriate readability level of text and appropriate pictures to accompany the texts.

\section{Design Phase}

In developing the product in this study, there were some steps that followed by the writer; first step was writing the learning objectives which had been identified in the analysis phase. The next step was collecting all information about agricultural products in Lubuklinggau which was done by interviewing the farmers or the sellers of each agricultural product in Lubuklinggau. Furthermore, the information was written in English according to eighth grade students' syllabus. After being translated and developed, the developed descriptive texts were checked in terms of its readability levels by using an online tool of Automated Readability Index (i.e.: https://readability-score.com/).

In line with what was suggested by the writer's advisors, reading materials had to have 1 text which was exactly matched with the students' reading level, 2 texts which had to be 2 levels above students 'reading level, and 2 texts which had to be 2 levels below students' reading level. Since the students' reading level was at level 3, the readability levels of the stories had to be at level 1, 2, 3, 4, and 5 . Finally, levels in reading material are carefully graded from starter to upper intermediate to help the students choose the right material for their ability (Macmillan, 2014:56).

Additionally, in paper-based design, ten descriptive texts were divided into two different products; the developed local content-based reading material and the developed reading comprehension test. In reading materials, each developed text, was followed by the exercises in form of various type of test such as Multiplechoice, Essay and True false. Meanwhile, in developed reading comprehension, 5 descriptive texts were then completed by 50 questions in form of multiple-choice question which covered six aspects of reading; they were main idea, detail, vocabulary, inference, cause-effect and sequence. All of the items were appropriately constructed in line with the indicators which had been created in the analysis phase. 


\section{Evaluation and Revision Phase}

\section{Self-Evaluation}

By considering the results of students' reading level and needs analysis, the book, entitled Readings:Descriptive texts of agricultural products of Lubuklinggauconsisting of reading materials and reading comprehension test were constructed in this phase. The writer also designed and matched the layout of the cover such as the words and pictures with the title of the developed product. The writer, then, reread the developed product along with revising some misspelling, and punctuation before it was given in the experts review.

\section{Expert Review}

This expert review phase aimed to know whether the developed product was valid or not. In order to fulfill this aim, two experts were involved to evaluate the content (English) and construct (instructional design) of developed reading material and reading comprehension test. After reviewing the product, the two experts stated that the product was valid with revision. The writer, then, changed or redesigned the developed product based on what was suggested.

Meanwhile, the result of expert review showed that the prototype of the product was categorized as having high validity as indicated by the average score of questionnaires on content and construct which was 3.23 (see Appendix C).

\section{One-to-One Evaluation}

Three students as the representative of one student who belonged to high reading level, one other student with medium reading level, and the last one who belonged to low reading level were involved in this phase. Each student was firstly given developed product, after that, they gave their judgments through a questionnaire and put their comments on it (see Appendix D).Furthermore, the writer revised the developed product as suggested by the students in comment space of the questionnaire.

Furthermore, the overall practicality of the developed local content-based instructional graded reading materials, were then determined based on the average scores of 16 items of the questionnaire. As the results, developed instructional graded reading material was considered as highly practical as indicated by the average score of questionnaire which was 3.39

\section{Small Group Evaluation}

Nine students as the representative of three students who belonged to the low reading level, three students with medium reading level, and three students who belonged to the high reading level were involved in this phase. As similar to one-to-one evaluation, each student was given developed product, after that, the same questionnaire was given to obtain their response and comments (see Appendix E). The students' comments showed that all students liked the developed product in this study. In addition, the nine students involved in small 
group phase were also agree that developed product were very attractive, clear, and easy to be understood. In this phase, therefore, there was no change made.

Moreover, since the average score of the forth aspects of local contentbased graded reading materials which consist of: (1) the match between materials and students' characteristics; (2) material presentation; (3) aspects of evaluation; and (4) the attractiveness of developed local content-based instructional graded reading materials was 3.18 , therefore, it can be considered that developed instructional graded reading material was practical with 'Very High Category'.

\section{Field test}

In field test, a real class of the eighth grade students of SMP Negeri 11 Lubuklinggau consisting 27 students were involved, however, the students participating in one-to-one and small group evaluation were not involved anymore. In this phase, the students were individually given developed reading comprehension test consisting 50 multiple-choice questions. The students' score in the field test was used to measure the effctiveness, the validity, the reliability, the difficulty index and discrimination index of developed reading comprehension test. As the findings, reading comprehension test could be categorized as effective because there were 20 students $(74.07 \%)$ out of 27 students in reading comprehension test reached average category which was between 56 and 70 .

Moreover, the developed test was also considered having high criterion related validity as indicated by the result of Pearson correlation of the two set of score in this study which was $r=0.86$. Additionally, the scores of each reading aspects (categorized as literal, inferential and vocabulary) in reading comprehension test were also partially correlated to the ones included in reading level test as indicated by Beta coefficient value was 0.44 (literal), 0.71(inferential) and 0.50 (vocabulary).

Furthermore, the test was also considered reliable as indicated by the value of Cronbach's Alpha obtained which was 0.94. Moreover, the result of items validity showed that all items test were valid as indicated by the value of the $r$ obtained of each item which was belonged to very beneficial criterion. According to Saad, Carter, Rothenberg, and Israelson, (1999:34), validity and reliability are the technical properties that indicate the quality and usefulness of the test. Considering that statement, thus it can be said that developed test has good quality as reading assessment.

In addition to reliability and validity of the test, the results of index of difficulty showed that all items of developed reading test felt in medium criterion, according to Heaton (1989:23), the index of difficulty of an item simply reflects how easy of difficulty the particular item proved in the test. Regarding that theory, thus, it was concluded that all items of developed test were appropriate (neither too easy nor too difficult) for the students. Additionally, based on the result of 
discrimination index; 17 items in developed test felt in moderate category; while other 33 items were in good category. According to Heaton (1989:23), discrimination index measures how well the test items were arranged to identify the differences in the student's competence. Hence, it can be concluded that all items of developed reading test in this study were good in separating more able student from the less able student.

\section{DISCUSSION}

There are step that the writer did before developed the product, the writer firstly analyzed the reading materials used in SMPN 11 Lubuklinggau. The materials analyzed were the descriptive texts available in the textbook as the only learning source used by the Eighth grade students of that school entitled 'English in Focus'. The result of analysis showed that there were only 3 descriptive texts in the textbook, entitled 'The Sea Eagle', 'Cockatoos' and 'Bongo the Orangutan' with readability levels $7.5,9.3$, and 4.2 respectively. Responding the result the writer think that the new reading materials that is provided many readability levels are needed.

In addition to textbook analysis, in this phase, the writer also did curriculum analysis to determine the learning objectives for developed instructional reading materials. As the result, the writer found that SMP N 11 Lubuklinggau uses curriculum KTSP (2006), while the standard competence of teaching reading for the Eighth grade students is "Understanding the meaning of written functional text and simple short essays in the form of descriptive and recount that related to the environment".

Moreover, the writer also conducted students' needs analysis. In this phase, the aim of students' needs analysis was intended to obtain information about students' needs in terms of reading material. To fulfill that aim, a questionnaire was administered to 27 eighth grade students. There were 20 questions which covered 6 aspects; they were (1) their perception about their reading skill; (2) their perception of the learning process; (3) their perception about the reading materials in their textbook; (4) their expectations on the content of reading materials; (5) their knowledge about Lubuklinggau agricultural products, and (6) their expectations on the developed instructional reading materials.

The third analysis was to find out the students' reading level. A Group Informal Reading Inventory: An Instrument for the Assessment of ESL Students ' Reading Performance developed by Stark (1981:34) which included the reading texts at level 1, 2, 3, 4 and 5 was given to the two classes of the eighth grade students at SMP N 11 Lubuklinggau. The results of this test shows that students' reading level was at level 3 , because the percentage of the students who belonged 
to level 3 was the highest of all. Responding those results, the product, therefore were developed in 5 levels there are level 1, level 2, level 3, level 4 and level 5.

\section{CONCLUSION}

From the results discussed previously, there are some conclusions, that the developed local content-based instructional reading materials were highly valid in terms of its content (English), and construct (instructional design) after being reviewed by two experts in expert review phase. Next, the developed reading materials were considered as highly practical after being evaluated by the students in one-to-one evaluation and small group evaluation. Therefore, the developed local content-based reading comprehension was effective to be used as reading assessment because there were 20 students (74.07\%) out of 27 students in reading comprehension test reached average category which was between 56 and 70.Additionally, the writer realized that time of experiment is the most obvious limitation of this study. The writer has not finished yet measuring the potential effect of developed reading material. As the follow up, the writer, therefore, expects that developed local content-based reading materials with the readability level of 1,2,3,4, and 5 can be continuously measured in further research by involving much more number of students and may be held in collaboration with the English teachers of all junior high schools in Lubuklinggau.

\section{REFERENCES}

Addision, J. (1996). Definition of reading. Retrieved fromhhtp://www.siu.edu/arc/chapter3.html-14k

Akker, J. (1999). Principle and methods of development research.In J. Akker, R. Branch, K. Gustalfon, T. Nieveen N, \&Plomp (Eds.).Design methodology and development research (pp. 1-14). London: Kluwer.

Avruch, K. (1998). Culture and conflict resolution. Washington, DC: United States Institute of Peace Press.

Ballantyne, P. (2002). Collecting and propagating local development content. Retrieved fromhttp://www.bibalex.org/Search4Dev/files/287986/118903.pdf.

Baswedan, A., Srihadi, E., Yusuf, A., Korban, A. W., \&Yuda, H. Y. (2010).Tinjuanbulananekonomi, hukum, keamanan, politikdansosial.Update Indonesia, 5(6), 1979-1984.

Bomer, R. (1995). Time for meaning: Crafting literate lives in middle and high school. Portmouth, NH: Heinemann.

Brown, H. D. (2007). Principles of language learning and teaching $\left(5^{\text {th }}\right.$ ed.). New York, NY: Pearson Education.

Central Bureau of Statistics Lubuklinggau.(2013). Hasilsensuspertanian 2013.Retrieved from http://bit.ly/1REJOPW 
Cooper, J. D., Warncke, E. W., \& Shipman, D.A. (1988). What and how reading instruction. Columbus, $\mathrm{OH}$ : Merril Publishing Company.

Dharma, A. (2008).Indonesia basic education curriculum current content and reform.Retrieved fromhttp://www.ibe.unesco.org/curricula/indonesia/io_befw_2008_eng.pdf

Heaton, J. B. (1989).Writing English language test. New York, NY: Longman Group UK Limited.

Hughes, A. (1989). Testing for language teachers. New York, NY: Cambridge University Press.

Kellerman, S. (1996).The psychology of verbal comprehension.Harlow, Essex: Longman Group Ltd.

Kubiszyn, T., \&Borich, G. (1993).Educational testing and measurement: Classroom application and practice $\left(4^{\text {th }}\right.$ ed.). New York, NY: Harper Collins College Publisher.

Lauder, A. (2008). The status and function of english in indonesia: A review of key factors. MakaraSosialHumaniora. 12(1), 9-20.

LubuklinggauDalamAngka.(2013). Kota Lubuklinggaudalamangka 2013. Retrieved from http://bit.ly/1P1nomL

Macmillan. (2014). Using graded readers in the classroom. Retrieved from http://bit.ly/1k2sa4d

Malone, S. (2013). Resource for developing graded reading materials for mother tongue-based education. Retrieved from http://bit.ly/1PQGVM3

Nation, P., \& Ming-tzu, K. W. (1999).Graded readers and vocabulary.Reading in a Foreign Language, 12(2), 355-379.

National Resource Governance Institute. (2015). Local content. Retrieved from http://www.resourcegovernance.org/sites/default/files/nrgi_LocalContent.pdf

Noble, J. (2014).COMP6053 lecture: Relationship between two variables: Correlation, covariance and r-squared. Retrieved from http://bit.ly/28VNdMs

Pitaloka, N. L. (2014). Developing interactive multimedia with local-contentbased narrative texts for the eighth grade students. (Unpublished master's thesis).University of Sriwijaya, Palembang, Indonesia.

Prastiwi, Y. (2013). Transmitting local cultural knowledge through English as foreign language (EFL) learning as a means of fostering "unity in diversity".Academic Journal of Interdisciplinary Studies, 2(3), 507-513.

Richards, J. C. (2005). Materials Development and Research - Making the Connection. Retrieved from http://www.professorjackrichards.com/wpcontent/uploads/materials-development-making-connection.pdf

$\begin{array}{lllll}\text { Riyadi, } & \text { D. } & \text { M. } & \text { (2004). }\end{array}$ KebijakanpembangunansumberdayapesisirSebagaialternatifpembangunan indonesiamasadepan.Retrieved from http://bappenas.go.id/

Saad, S., Carter, G. W., Rothenberg, M., \&Israelson, E. (1999).Testing and assessment: An employer's guide to good practices. Washington, DC: Educational Resources Information Center. 
Stark, M. W. ((1981). A group informal reading inventory: An instrument for the assessment of ESL students' reading performance. Retrieved from http://bit.ly/183SDUW

Subana, M. \&Sudrajad.(2005). Dasar-dasarpenelitianilmiah.Bandung: PestakaSetia.

Tessmer, M. (1993).Planning and conducting formative evaluation.Philadehelphia, PA: Kogan Page.

The Mayor of Lubuklinggau's regulation number 31 Year 2014. (2014). PeraturanwalikotaLubuklinggau No $31 \quad$ Tahun 2014 TentangPembentukanLembagaAdat Kota Lubuklinggau. Retrieved from http://bit.ly/28VxMUu

Tomlinson, B. (2011). Material development in language teaching. Cambridge: Cambridge University Press.

Tomlinson, B. (2012). Materials development for language learning and teaching.Language Teaching, 42(2), 143-179.

Ubbe, A. (2011). PengkajianHukumTentangPerlindunganHukumKebudayaan Daerah. Jakarta

Timur: BadanPembinaanHukumNasionalKementerianHukum

Dan HakAsasiManusia RI. Retrieved from http://bit.ly/1PRnxMJ

Utami, I. A., Nitiasih, P. K., \&Arini, L. P. (2014).Developing culture-based supplementary reading material for the eighth grade students of SMP laboratoriumSingaraja.e-Journal Program PascasarjanaUndiksha, 2(1), 112.

Waugh, K, C., \&Gronlund, N, E. (2013). Assessment of student achievement. Boston, NY: Pearson.

World Bank.(2003). Priority issues for Indonesia agriculture. Retrieved from 